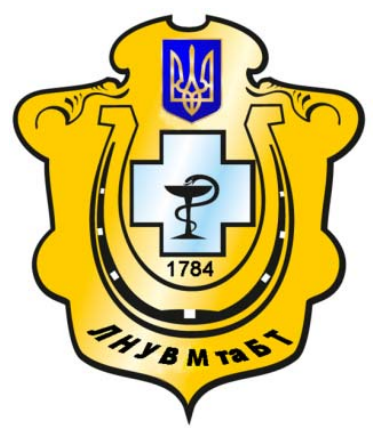

Науковий вісник Львівського національного університету ветеринарної медицини та біотехнологій імені С.3. Гжицького

Scientific Messenger of Lviv National University of Veterinary Medicine and Biotechnologies named after S.Z. Gzhytskyj

doi:10.15421/nvlvet7434

ISSN 2519-2698 print

ISSN 2518-1327 online

$\underline{\text { http://nvlvet.com.ua/ }}$

УДК [556.114:556.55]:574.5(28)(477.83)

\title{
Accumulation and distribution of zinc and manganese in aquatic ecosystem of Yavoriv water reservoir, Lviv region, Ukraine
}

\author{
G.M. Dobryanska ${ }^{1}$, D.O. Yanovych ${ }^{2}$, T.M. Shvets ${ }^{3}$, A.A. Butsyak ${ }^{2}$ \\ yandeni77@gmail.com \\ ${ }^{1}$ Lviv Research Station of Institute of Fisheries, \\ Lvivska Str., 11, u.s. Welykyj Ljubin, 81555, Ukraine; \\ ${ }^{2}$ Lviv National University of Veterinary Medicine and Biotechnologies named after S.Z. Gzhytskyi, \\ Pekarska Str., 50, Lviv, 79010, Ukraine; \\ ${ }^{3}$ Institute of Fisheries, \\ Obukhivska Str., 135, Kyiv-164, 03164, Ukraine
}

\begin{abstract}
The paper presents results of investigations of zinc and manganese concentration in the water, bottom deposits and ichthyofauna of Yavoriv water reservoir, which was formed in 2002 in frames of project of Yavoriv sulfur quarry revitalization. Mentioned elements are characterized by wide spectrum of action in fish body, which, depending on their concentration, can be either physiologic or toxic. It was revealed, that concentration of $\mathrm{Zn}$ and $\mathrm{Mn}$ in the water of Yavoriv water reservoir varied considerably depending on place of samples taking. The lowest Zn concentration in the water was below 1 MPL (maximum permitted level), namely $0.6 \mu g / l$, and the highest - more than $7 \mathrm{MPL}(70.5 \mu \mathrm{g} / \mathrm{l})$. Similar differences were observed concerning Mn concentration in the water - the range of determined values varied from 3.3 (0.3 MPL) to $48.6 \mu \mathrm{g} / \mathrm{l}$. The same peculiarities of Zn and Mn distribution were estimated in regard to their content in bottom deposits. In particular, difference of Zn concentration in samples of bottom deposits was near 23 times - from 5.4 to $230.0 \mathrm{mg} / \mathrm{kg}$ depending on the point of samples taking. Mn content in bottom deposits varies from 61.5 to $1500 \mathrm{mg} / \mathrm{kg}$. Zn and Mn concentration in skeletal muscles, gills and skin of perch and rudd didn't exceed MPL regardless their content in the water and bottom deposits. In most of cases, gills accumulated these elements more than other investigated tissues.

Key words: zinc, manganese, aquatic ecosystem, water reservoir, water, bottom deposits, rudd, perch, organs, tissues.
\end{abstract}

\section{Накопичення та розподіл цинку і марганцю у водній екосистемі Яворівського водосховища, Львівська область, Україна}

\author{
Г.М. Добрянська ${ }^{1}$, Д.О. Янович ${ }^{2}$, Т.М. Швець ${ }^{3}$, Г.А. Буцяк ${ }^{1}$ \\ yandeni77@gmail.com \\ ${ }^{1}$ Львівська дослідна станиія Інституту рибного господарства НААНУ, \\ вул. Львівська, 11, смт Великий Любінь, 81555, Украӥна; \\ ${ }^{2}$ Львівський національний університет ветеринарної медицини та біотехнологій імені С. З. Гюицького, \\ вул. Пекарська, 50, м. Львів, 79010, Украӥна; \\ ${ }^{3}$ Інститут рибного господарства НАAН, \\ вул. Обухівська, 135, м. Київ-164, 03164,Украӥна
}

В роботі представлені результати дослідження вмісту Цинку та Марганцю у воді, донних відкладах та іхтіофауні Яворівського водосховища, яке було створено у 2002 роиі в рамках проекту з відновлення територій Яворівського сірчаного кар'єру. Вказані елементи характеризуються широким спектром дії в організмі риб, яка, залежно від їх концентрації, може бути фізіологічною чи токсичною. Було встановлено, шцо концентрація Цинку та Марганщю у воді Яворівського водосховища значно відрізнялася залежно від місия відбору проби. Найнижчий вміст Цинку у воді був нижчим ніж 1 ГДК (гранично допус-

\section{Citation:}

Dobryanska, G.M., Yanovych, D.O., Shvets, T.M., Butsyak, A.A. (2017). Accumulation and distribution of zinc and manganese in aquatic ecosystem of Yavoriv water reservoir, Lviv region, Ukraine. Scientific Messenger LNUVMBT named after S.Z. Gzhytskyj, 19(74), 152-155. 
тимої концентрачії), а саме 0,6 мкг/л, а найвищий - на рівні понад 7 ГДК (70,5 мкг/л). Подібні відмінності були відмічені стосовно вмісту Марганияю у воді - діапазон встановлених кониентрацій змінювався від 3,3 (0,3 ГДК) до 48,6 мкг/л. Подібні особливості розподілу Цинку і Марганцю були встановлені також стосовно їхнього вмісту у донних відкладах. Зокрема, різниці у вмісті Цинку в зразках донних відкладів становили близько 23 разів - від 5,4 до 230 мг/кг залежно від місия відбору зразка. Вміст Марганиџю у донних відкладах змінювався від 61,5 до 1500 мг/кг. Конщентрачія ичинку та марганщю в скелетних м'язах, зябрах і шкірі окуня та краснопірки не перевищувала ГДК, незалежно від їхнього вмісту у воді та донних відкладах. В більшості випадків, зябра накопичували иі елементи більшою мірою, ніж інші досліджувані тканини.

Ключові слова: Цинк, Марганеиь, гідроекосистема, водосховище, вода, донні відклади, краснопірка, окунь, органи, тканини.

\title{
Накопление и распределение цинка и марганца в водной экосистеме Яворовского водохранилища, Львовская область, Украина
}

\author{
А.Н. Добрянская ${ }^{1}$, Д.А. Янович ${ }^{2}$, Т.М. Швец ${ }^{3}$, А.А. Буцяк ${ }^{1}$ \\ yandeni77@gmail.com \\ ${ }^{1}$ Львовская опытная станция Института рыбного хозяйства НААНУ, \\ ул. Львовская, 11, пгт Великий Любень, 81555, Украина; \\ ${ }^{2}$ Львовский нацииональный университет ветеринарной медицины и биотехнологий имени С.3. Гжицкого, \\ ул. Пекарская, 50, г. Львов, 79010, Украина; \\ ${ }^{3}$ Институт рыбного хозяйства НААНУ, \\ ул. Обуховская, 135, г. Киев-164, 03164, Украина
}

\begin{abstract}
В работе представлены результаты исследования содержания Цинка и Марганца в воде, донных отложениях и ихтиофауне Яворовского водохранилища, созданного в 2002 году в рамках проекта восстановления территорий Яворовского серного карьера. Указанные элементы характеризуются широким спектром действия в организме рыб, которое, в зависимости от концентрации, может быть физиологическим либо токсическим. Было установлено, что конщентрация Цинка и Марганца в воде Яворовского водохранилища значительно отличалась в зависимости от места отбора пробы. Минимальное содержание Цинка в воде составляло ниже 1 ПДК (предельно допустимой концентрации), а именно 0,6 мкг/л, а максимальное - на уровне более 7 ПДК (70,5 мкг/л). Подобные отличия были установлены касательно содержания Марганиа в воде - диапазон установленных кониентраций находился в пределах 3,3 (0,3 ПДК) - 48,6 мкг/л. Подобные особенности распределения Цинка и Марганиа были выявлены также в отношении их содержсания в донных отложениях. В частности, различия в содержании Цинка в образиах донных отложений составляли около 23 раз - от 5,4 до 230 мг/кг в зависимости от места отбора проб. Содержание Марганиа в донных отложениях находилось в пределах 61,5-1500 мк/кг. Концентраичия циннка и марганцуа в скелетных мышиах, жабрах и коже окуня и красноперки не превышала ПДК независимо от их уровня в воде и донных отложениях. В большинстве случаев жабры накапливали эти элементы в наибольшей степени в сравнении с другими исследуемыми тканями.
\end{abstract}

Ключевые слова: Цинк, Марганеи, гидроэкосистема, водохранилище, вода, донные отложения, красноперка, окунь, органы, ткани.

\section{Introduction}

Anthropogenic transformation and industrial pollution of landscapes belongs to important ecological problems in Ukraine; their solution can be realized in number of ways, including hydrological technique, introduction of sustainable plants, land development etc. Rehabilitation of technogenic landforms by formation of artificial water bodies is rational due to both ecological and economical backgrounds (Szabo et al., 2010). Yavoriv water storage reservoir was formed in 2002 in frames of project of Yavoriv sulfur quarry revitalization. Filling of the reservoir with water lasted from 2002 to 2006; nowadays it is one of the largest artificial waterbodies in Ukraine with the total volume of near 200 million $\mathrm{m}^{2}$ and depth up to $70 \mathrm{~m}$ (Taras, 2013). Water supplementation of the reservoir is provided by Schklo River - the tributary of San River from Vistula River basin. Ichthyofauna of reservoir is presented by pike (Esox lucius), common carp (Cyprinus carpio), sulver carp (Hypophthalmichthys nobilis), roach (Rutilus rutilus), Prussian carp (Carassius gibelio), perch (Perca fluviatilis) and rudd (Scardinius erythrophthalmus). Perspectives of further use of Yavoriv water reservoir comprise mainly recreation activity and fisheries, but possibilities of their implementation are limited by water body ecological conditions, including heavy metals concentration in the water.

The aim of our research was determination of $\mathrm{Zn}$ and Mn concentration in the water, bottom deposits and ichthyofauna of Yavoriv water reservoir. Due to their physical properties, both of this elements belongs to the group of heavy metals - common pollutants of aquatic ecosystems; meanwhile they acts also as essential trace elements with wide spectrum of biological activity in living beings (Dobryanska et al., 2013). Both deficiency and excess of $\mathrm{Zn}$ and $\mathrm{Mn}$ negatively affected metabolism in fish bodies. Biological activity of $\mathrm{Zn}$ is determined by its incorporation in alkaline phosphatase, carbonic anhydrase, carboxypeptidase, collagenase, mannosidase and superoxide dismutase enzymes (Yanovych and Yanovych, 2014). Zinc deficiency leads to inhibition of abovementioned enzymes activity, disruption of development, growth delay and increased mortality (Yanovych and Yanovych, 2014); at the same time, high concentrations of zinc in the water may cause kidneys lesions in fish body, fertility oppression and decreasing of growth rate (Hrytsyniak et 
al., 2015). Due to influence on corresponding enzymes activity, Mn realizes its effect on protein, lipids and carbohydrates metabolism and on antioxidant system efficiency (Yanovych and Yanovych, 2014). Mn deficiency may accompany with cataract development and abnormalities of bones, while toxic doses of Mn may cause lesions of hematopoietic tissue and disorders of ions transport (Hrytsyniak et al., 2015).

\section{Materials and methods}

Samples of water, bottom deposits as well as samples of tissues of rudd and perch from Yavoriv water storage reservoir were used in research. Samples of water and bottom deposits were taken in three points (Pic. 1) - №1 (50 meters from Schklo River estuary), №2 (50 meters from Yaksha River estuary) and №3 (pelagic part of water reservoir).

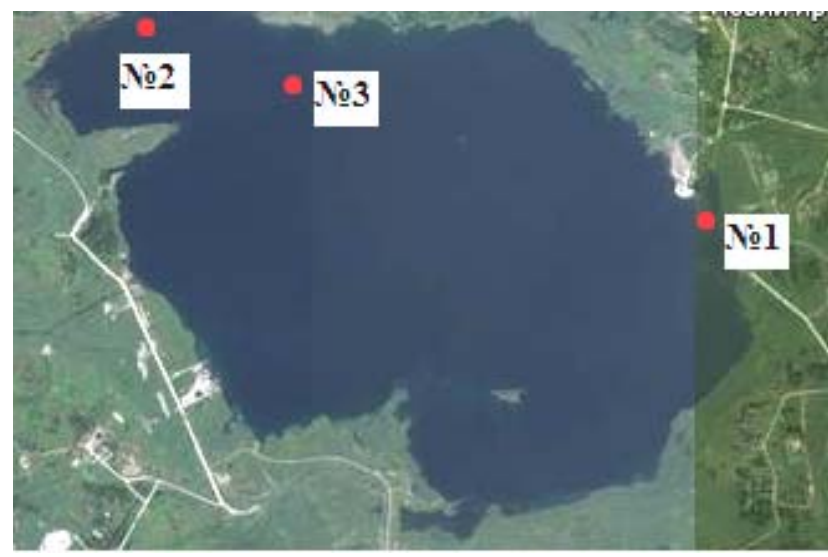

Pic. 1. Points of samples taking
Water samples were taken at $0.5 \mathrm{~m}$ depth. Fishes were slaughtered via striking of the cranium, according to the demands of European convention for the protection of vertebrate animals used for experimental and other scientific purposes; after slaughter samples of skeletal muscles, gills and skin were taken. Selected samples in 5 g quantity were placed in the flasks, filled with $20 \% \mathrm{HCl}$ solution and boiled at electric stove for 30 minutes. Then, after cooling, solutions of samples were filtered and added with bidistilled water up to $200 \mathrm{ml}$. In obtained samples $\mathrm{Zn}$ and Mn concentration was evaluated with atomic absorption spectroscopy method at wave length 213.8 and $257.6 \mathrm{~nm}$ correspondingly (Price, 1972). Obtained data were processed statistically.

\section{Results and discussion}

The data presented in Table 1 testified the fact that $\mathrm{Zn}$ and $\mathrm{Mn}$ concentration in the water and bottom deposits of Yavoriv water reservoir varied considerably depending on place of sample taking. In particular, the lowest observed $\mathrm{Zn}$ concentration in the water was below $1 \mathrm{MPL}$, namely $0.6 \mu \mathrm{g} / \mathrm{l}$, and the highest - more than $7 \mathrm{MPL}(70.5 \mu \mathrm{g} / \mathrm{l})$. Similar differences were observed concerning Mn concentration in the water - the range of determined values varied from $3.3 \mu \mathrm{g} / 1$ in point №1 $(0.3 \mathrm{MPL})$ to $48.6 \mu \mathrm{g} / 1$ in point №3 (more than 4 MPL). The same peculiarities of $\mathrm{Zn}$ and $\mathrm{Mn}$ distribution were estimated in regard to their content in bottom deposits. In particular, difference of $\mathrm{Zn}$ concentration in samples of bottom deposits was near 23 times - from $5.4 \mathrm{mg} / \mathrm{kg}$ in point №1 to $230.0 \mathrm{mg} / \mathrm{kg}$ in point №2.

$\mathrm{Zn}$ and $\mathrm{Mn}$ concentration in the water and bottom deposits of Yavoriv water reservoir $(\mathrm{M} \pm \mathbf{m}, \mathbf{n}=\mathbf{4})$

\begin{tabular}{|c|c|c|c|c|c|c|}
\hline \multirow{2}{*}{$\begin{array}{ll}\text { Object of research } & \\
\end{array}$} & \multicolumn{3}{|c|}{ Zn concentration } & \multicolumn{3}{|c|}{ Mn concentration } \\
\hline & 1 & 2 & 3 & 1 & 2 & 3 \\
\hline Water, $\mu \mathrm{g} / 1$ & $0.6 \pm 0.01$ & $70.5 \pm 2.37$ & $10.2 \pm 0.92$ & $3.3 \pm 0.07$ & $15.0 \pm 0.80$ & $48.6 \pm 1.67$ \\
\hline MPL & \multicolumn{3}{|c|}{10.0} & \multicolumn{3}{|c|}{10.0} \\
\hline Bottom deposits, $\mathrm{mg} / \mathrm{kg}$ & $10.1 \pm 0.09$ & $5.4 \pm 0.12$ & $230.0 \pm 17.26$ & $128.5 \pm 8.5$ & $61.5 \pm 3.48$ & $1500.0 \pm 68.92$ \\
\hline
\end{tabular}

At the same time, Mn content in bottom deposits varies from $61.5 \mathrm{mg} / \mathrm{kg}$ (point №2) to $1500 \mathrm{mg} / \mathrm{kg}$ (point №3) - the observed difference of concentration was near 24 times. Thus, obtained results evident the fact, that there is no evident dependence between $\mathrm{Zn}$ and $\mathrm{Mn}$ content in water and bottom deposits; at the same time, the fact of this metals accumulation in bottom deposits in greater measure than in water was approved in all points of samples taking. Presented results confirms the fact of heavy metals above normal accumulation in the water and bottom deposits of Yavoriv water reservoir, which was previously established in our studies (Dobryanska et al., 2015; Dobryanska et al., 2016).

The data presented in Table 2 confirms the existence of species and tissue peculiarities of $\mathrm{Zn}$ and $\mathrm{Mn}$ accumulation in rudd and perch body. In despite the exceeding of $\mathrm{Zn}$ and $\mathrm{Mn}$ concentration in the water and bottom deposits, their content in tissues of rudd and perch was unexpectedly within frameworks of MPL in most of cases.
Regardless the fact, that this fish species didn't have any commercial importance, concentration of heavy metals in their tissues can be used as an indicator of aquatic ecosystem pollution. Concentration of heavy metals in organs and tissues of different fish species and their influence on metabolism can serve as a part of a complex system of aquatic environment biomonitoring (Yanovych et al., 2016).

Presented results of our research shows, that $\mathrm{Zn}$ concentration in skeletal muscles, gills and skin of perch didn't exceed existing limits. Meanwhile, peculiarities of $\mathrm{Zn}$ accumulation ratio in above mentioned organs and tissues were established - the element content increased in row skeletal muscles $<$ skin $<$ gills. The same tissue dependence of $\mathrm{Zn}$ distribution in fish body was revealed also for rudd; at the same time, $\mathrm{Zn}$ concentration in gills of rudd shows three fold exceeding of maximum permitted level. 
$\mathrm{Zn}$ and Mn concentration in the tissues of Yavoriv water reservoir ichthyofauna, $\mathrm{mg} / \mathrm{kg}(\mathrm{M} \pm \mathrm{m}, \mathrm{n}=4)$

\begin{tabular}{|c|c|c|}
\hline Object of research & Zn concentration & Mn concentration \\
\hline $\begin{array}{r}\text { Rudd (Scardinius erythrophthalmus) } \\
\text { skeletal muscles } \\
\text { gills } \\
\text { skin }\end{array}$ & $\begin{array}{c}3.50 \pm 0.09 \\
120.20 \pm 9.65 \\
40.80 \pm 2.48\end{array}$ & $\begin{array}{l}2.64 \pm 0.08 \\
3.27 \pm 0.06 \\
0.68 \pm 0.02 \\
\end{array}$ \\
\hline $\begin{array}{r}\text { skeletal muscles } \\
\text { gills } \\
\text { skin }\end{array}$ & $\begin{array}{c}4.50 \pm 0.18 \\
17.30 \pm 0.09 \\
8.20 \pm 0.12 \\
\end{array}$ & $\begin{array}{l}0.16 \pm 0.01 \\
3.04 \pm 0.02 \\
5.53 \pm 0.09 \\
\end{array}$ \\
\hline$M P L$ & 40.0 & 20.0 \\
\hline
\end{tabular}

Concentration of $\mathrm{Mn}$ in investigated tissues of rudd and perch was within permitted limits, but its distribution in fish body differed from distribution of $\mathrm{Zn}$. In rudd body accumulation of $\mathrm{Mn}$ increased in row skin $<$ skeletal muskles $<$ gills, whereas in perch body it increased in row skeletal muscles $<$ gills $<$ skin. Mentioned peculiarities of heavy metals accumulation in fish organs and tissues can be explained by the fact, that fishes intakes mineral elements not only alimentary, but also through the skin and, especially, gills. At high concentrations of heavy metals in the water, gills can be considered as a protective barrier against their intake.

\section{Conclusions}

The results, presented in the paper, shows, that concentration of $\mathrm{Zn}$ and $\mathrm{Mn}$ in the water of Yavoriv water reservoir varied considerably depending on place of sample taking. $\mathrm{Zn}$ and $\mathrm{Mn}$ content were lowest within 50 meters from Schklo River estuary, whereas Zn concentration was highest within 50 meters from Yaksha River estuary, and Mn concentration was highest in the pelagic part of water reservoir. These differences of heavy metals distribution in the water can be explained by their different level in the water of Schklo River and Yaksha River. It is known, that level of heavy metals in small rivers greatly influenced by anthropogenic activity, and can change in dependence on agricultural or industrial load on the area. In its turn, the ecological status of small rivers influences on water bodies, which they filled.

There was no evident correlation between $\mathrm{Zn}$ and $\mathrm{Mn}$ content in water and bottom deposits, though the latest accumulated these metals more, than the water, in most of cases. At the same time, the magnification level of $\mathrm{Zn}$ and Mn was different in each point of samples taking.

$\mathrm{Zn}$ and $\mathrm{Mn}$ concentration in skeletal muscles, gills and skin of perch and rudd didn't exceed MPL regardless their content in the water and bottom deposits. In most of cases, gills accumulated these elements more than other investigated tissues, what pointed on dominant role of this organ in processes of heavy metals intake by fishes.

Perspective for further research. Analysis of heavy metals content in abiotic and biotic components of artificial aquatic ecosystems has a great importance for monitoring of environmental status of industrial landforms during rehabilitation process.

\section{References}

Szabo, J., David, L., Loczy, D. (2010). Anthropogenic Geomorphology: A Guide to Man-Made Landforms. Springer Science+Business Media B.V.

Taras, U.M. (2013). The revegetation problems of sulphuric pit during activity of the Yavoriv state mineschemical enterprise. Scientific bulletin of UNFU. 23.3, 154-158 (in Ukrainian).

Dobryanska, G.M., Melnyk, A.P., Yanovych, D.O., Shvets, T.M. (2013). Heavy metals accumulation in different species of food fish. Scientific Messenger LNUVMBT named after S.Z. Gzhytskyj. 15, 1(55), 52-56 (in Ukrainian).

Yanovych, N.E., Yanovych, D.O. (2014). Trace elements role in pond fishes vital functions. Scientific Messenger LNUVMBT named after S.Z. Gzhytskyj. 16, 2(59), 345-372 (in Ukrainian).

Hrytsyniak, I.I., Yanovych, D.O., Shvets, T.M. (2015) Ecotoxicology of Salmonids. Kiev, Publishing House DIA (in Ukrainian).

Price, W.J. (1972). Analytical Atomic Absorption Spectrometry. Heyden and Son Ltd., London.

Dobryanska, G.M., Melnyk, A.P., Yanovych, N.E., Yanovych, D.O. (2015). Cadmium and lead concentration in hydroecosystem of Yavoriv water storage basin. Scientific Messenger LNUVMBT named after S.Z. Gzhytskyj. 1(61), 263-267 (in Ukrainian).

Dobryanska, G.M., Melnyk, A.P., Yanovych, N.E., Yanovych, D.O. (2015). Iron and copper concentration in hydroecosystem of Yavoriv reservoir. Scientific Messenger LNUVMBT named after S.Z. Gzhytskyj. 1(65), 265-269 (in Ukrainian).

Dobryanska, G.M., Yanovych, D.O., Shvets, T.M., Butsyak, A.A. (2016). Cobalt and nickel concentration in the water, bottom deposits and ichthyofauna of Yavoriv water storage basin. Scientific Messenger LNUVMBT named after S.Z. Gzhytskyj. 18, 2(67), 90-93 (in Ukrainian).

Yanovych, D.O., Hrytsyniak, I.I., Shvets, T.M. (2016). Application of Salmonids in aquatic quality biomonitoring. Fisheries Science of Ukraine. 1, 17-35 (in Ukrainian).

Стаття надійшла до редакциї 22.03.2017 